Table 1. Population characteristics, and physician reported satisfaction with secukinumab

\begin{tabular}{|c|c|c|c|c|}
\hline & \multicolumn{2}{|c|}{ Population characteristics } & \multicolumn{2}{|c|}{ Satisfaction level } \\
\hline & $\begin{array}{c}\text { N (\%) PsA patients } \\
\text { in each category } \\
(n=438)\end{array}$ & $\begin{array}{c}N(\%) \text { AS } \\
\text { patients in } \\
\text { each category } \\
(n=277)\end{array}$ & $\begin{array}{c}\text { N (\%) PsA } \\
\text { physicians } \\
\text { satisfied } \\
(n=438)\end{array}$ & $\begin{array}{c}\mathrm{N}(\%) \text { AS } \\
\text { physicians } \\
\text { satisfied } \\
(\mathrm{n}=277)\end{array}$ \\
\hline $\begin{array}{l}\text { Overall } \\
\text { satisfaction }\end{array}$ & - & - & $385(87.9)$ & $239(86.3)$ \\
\hline Severity at & $28(6.4)$ & $5(1.8)$ & $18(64.3)$ & $4(80.0)$ \\
\hline initiation* & $236(54.3)$ & $128(46.2)$ & $210(89.0)$ & $109(85.2)$ \\
\hline $\begin{array}{l}\text { Mild } \\
\text { Moderate } \\
\text { Severe }\end{array}$ & $171(39.3)$ & $144(52.0)$ & $155(90.6)$ & $126(87.5)$ \\
\hline Prior biologic & $191(43.6)$ & $147(53.1)$ & $155(81.2)$ & $118(80.3)$ \\
\hline $\begin{array}{l}\text { use } \\
\text { Bio- } \\
\text { experienced } \\
\text { patients } \\
\text { Bio-naive } \\
\text { patients }\end{array}$ & $247(56.4)$ & $130(47.9)$ & $230(93.1)$ & $121(93.1)$ \\
\hline Secukinumab & $82(18.7)$ & $72(26.0)$ & $56(68.3)$ & $48(66.7)$ \\
\hline duration & $120(27.4)$ & $68(24.5)$ & $108(90.0)$ & 61 (89.7) \\
\hline $\begin{array}{l}1-4 \text { months } \\
>4-6 \text { months } \\
>6 \text { months }\end{array}$ & $236(53.9)$ & $137(49.5)$ & $221(93.6)$ & $130(94.9)$ \\
\hline Concomitant & $236(53.9)$ & $117(42.2)$ & $214(90.7)$ & $103(88.0)$ \\
\hline medication & $104(23.7)$ & $113(40.8)$ & $89(85.6)$ & $95(84.1)$ \\
\hline $\begin{array}{l}\text { Monotherapy } \\
\text { Combination } \\
\text { with a non- } \\
\text { csDMARD } \\
\text { Combination } \\
\text { with a } \\
\text { csDMARD }\end{array}$ & $98(22.4)$ & $47(17.0)$ & $82(83.7)$ & $41(87.2)$ \\
\hline
\end{tabular}

${ }^{*}$ PsA base size $=435$

Conclusion: This study provides insight into physician satisfaction with secukinumab in a real-world clinical setting. Physicians reported being highly satisfied with the ability of secukinumab to control PsA and AS disease, regardless of patient population subgroups.

Disclosure of Interests: Elizabeth Holdsworth Employee of: Adelphi Real World, Nicola Booth Employee of: Adelphi Real World, Steve Lobosco Employee of: Adelphi Real World, Olivia Massey Employee of: Adelphi Real World, Amie Scott Consultant for: Novartis Pharmaceuticals Corporation, Haijun Tian Shareholder of: Novartis Pharmaceutical Corporations, Employee of: Novartis Pharmaceutical Corporations, Dorothy Keininger Shareholder of: Novartis, Employee of: Novartis DOI: 10.1136/annrheumdis-2019-eular.4167

\section{THU0636 HIGHER SOCIAL MEDIA USER STICKINESS ON SELF- MANAGEMENT SYSTEM MAY IMPROVE THE REMISSION RATE OF PATIENTS WITH ANKYLOSING SPONDYLITIS}

Xiaojian Ji, Jian Zhu, Jianglin Zhang, Feng Huang, SpAMS co-authors. Chinese PLA General Hospital, Department of Rheumatology, Beijing, China

Background: With the advence of mobile health technologies, it is possible to set up economic management systems to improve health care. By using a Smart-phone Spondyloarthritis Management System (SpAMS), the Chinese Ankylosing Spondylitis (AS)/Spondyloarthritis Prospective Imaging Cohort (CASPIC) was launched.

Objectives: To explore the improvement of disease management and cost effectiveness of SpAMS for Chinese patients with AS

Methods: Patients enrolled in the CASPIC cohort who fulfilled the 1984 modified New York criteria and with at least 2 evaluations of Ankylosing Spondylitis Disease Activity Score (ASDAS) were included in this analysis. All physician-reported assessments were collected at the Chinese People's Liberation Army General Hospital using SpAMS in Beijing. The disease activity states were defined according to ASDAS1, which separated inactive disease (ID) from low disease activity (LDA) by 1.3, LDA from high disease activity (HDA) by 2.1, and HDA from very high disease activity (VHDA) by 3.5. According to ASDAS at the baseline visits and final visits, patients were divided into four groups (Figure 1): maintainer of ID/LDA, patients with relapse, maintainer of active disease, and new achiever of ID/LDA.

Results: From April 2016 to April 2018, 1201 patients with AS were enrolled in CASPIC. 4659 patient self-assessments were completed, including 3304 pre-visit assessments and 1355 assessments during the follow-up interval. After online consultation, $29.1 \%$ of clinic visits to a tertiary hospital were considered unnecessary and could be solved in the primary care hospital. The time and cost of each patient's journey to Beijing were calculated based on the location of each patient. For the 1037 $(86.3 \%)$ patients who lived outside the vicinity of Beijing, at least an average of 5.3 hours and $327.4 \mathrm{RMB}$ for each person (USD: RMB $=1: 6.418$ ) for traffic time and expenses were saved, which equaled to $16 \%$ of the Chinese monthly disposable personal income (data in 2016).

\begin{tabular}{|c|c|c|c|c|c|c|}
\hline \multirow[t]{2}{*}{ Characteristics } & \multicolumn{3}{|c|}{$\begin{array}{l}\text { ID/LDA at baseline } \\
(\mathrm{n}=445,57.2 \%)\end{array}$} & \multicolumn{3}{|c|}{$\begin{array}{l}\text { Active at baseline } \\
(\mathrm{n}=332,42.7 \%)\end{array}$} \\
\hline & $\begin{array}{c}\text { Maintainers } \\
\text { of ID/LDA } \\
(\mathrm{n}=410 \\
92.1 \%)\end{array}$ & $\begin{array}{c}\text { Patients } \\
\text { with } \\
\text { relapse } \\
(\mathrm{n}=35 \\
7.9 \%)\end{array}$ & $P$ value & $\begin{array}{c}\text { Maintainers } \\
\text { of active } \\
\text { disease } \\
(n=127 \\
38.2 \%)\end{array}$ & $\begin{array}{c}\text { New } \\
\text { achievers } \\
\text { of ID/LDA } \\
(\mathrm{n}=205 \text {, } \\
61.7 \%)\end{array}$ & $P$ value \\
\hline $\begin{array}{l}\text { Age, mean (s. } \\
\text { D.), years }\end{array}$ & $30.2(9.1)$ & $29.8(7.6)$ & 0.785 & $30.8(8.6)$ & $30.6(8.3)$ & 0.816 \\
\hline $\begin{array}{l}\text { Disease } \\
\text { duration, mean } \\
\text { (s.D.), years }\end{array}$ & $7.6(6.2)$ & $7.3(5.6)$ & 0.787 & $9.0(6.1)$ & $9.3(6.1)$ & 0.714 \\
\hline $\begin{array}{l}\text { Number of self- } \\
\text { assessments, } \\
\text { mean (s.D.) }\end{array}$ & $5.0(2.7)$ & $3.3(1.8)$ & $<0.001^{*}$ & $4.5(2.5)$ & $5.6(3.1)$ & $<0.001^{*}$ \\
\hline Male sex,\% & 79.8 & 88.6 & 0.207 & 89.8 & 83.9 & 0.133 \\
\hline $\begin{array}{l}\text { ASDAS at } \\
\text { baseline, mean } \\
\text { (S.D.) }\end{array}$ & $1.4(0.5)$ & $1.5(0.4)$ & $0.031^{*}$ & $3.2(0.8)$ & $3.0(0.8)$ & 0.134 \\
\hline Smoker,\% & 24.7 & 40.0 & $0.047^{*}$ & 44.0 & 32.8 & $0.042^{*}$ \\
\hline $\begin{array}{l}\text { NSAIDs at } \\
\text { baseline, } \%\end{array}$ & 98.1 & 99.8 & 0.448 & 97.9 & 99.4 & 0.263 \\
\hline $\begin{array}{l}\text { TNFi at } \\
\text { baseline, } \%\end{array}$ & 19.2 & 13.8 & 0.479 & 24.5 & 29.8 & 0.359 \\
\hline $\begin{array}{l}\text { DMARDs at } \\
\text { baseline,\% }\end{array}$ & 64.0 & 72.4 & 0.363 & 66.0 & 68.5 & 0.679 \\
\hline $\begin{array}{l}\text { TNFi during } \\
\text { follow-up } \\
\text { period }^{\mathrm{a}} \%\end{array}$ & 29.9 & 27.3 & 0.755 & 32.3 & 45.6 & $0.016^{*}$ \\
\hline
\end{tabular}

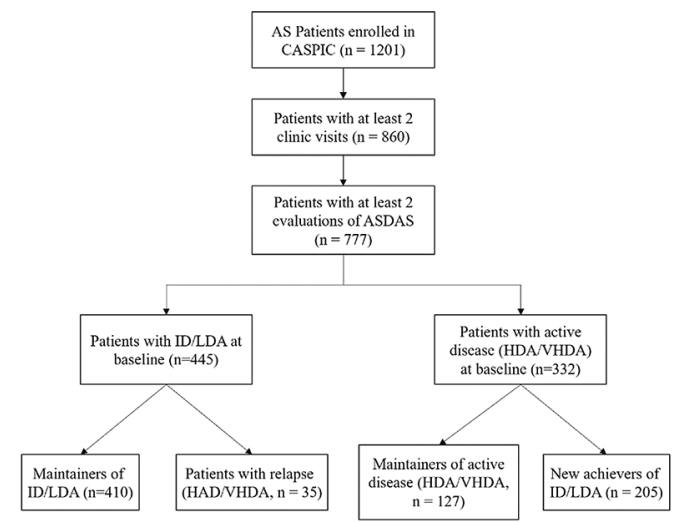

Figure 1. Flow chart of participants in the study

Abbreviation: ID: inactive disease: LDA: low disease activity; HDA: high disease activity; VHDA: very high disease activity

Of these patients enrolled in CASPIC, 777 patients had at least 2 evalu ations of ASDAS. The rate of patients with ID/LDA was $57.2 \%$ at baseline and increased significantly to $79.2 \%$ with a mean (SD) follow-up of 13.3 (5.9) months (Table 1). Compared with patients who relapsed, those that maintained the ID/LDA had more patient assessments $[5.0$ (2.7) vs 3.3 (1.8), $P<0.001]$. The new achievers of ID/LDA also completed online patient assessments more frequent [5.6 (3.1) vs 4.5 (2.5), $\mathrm{P}<$ 0.001] compared to patients who maintained active disease.

Conclusion: Higher social media user stickiness on self-management system may improve the remission rate of AS patients. SpAMS could serve as a cost- and time-saving specialty care online platform for patients with AS.

\section{REFERENCES:}

[1] Machado PM, Landewé R, Heijde Dvd. Ankylosing Spondylitis Disease Activity Score (ASDAS): 2018 update of the nomenclature for disease activity states. Ann Rheum Dis 2018:annrheumdis-2018-213184 
Disclosure of Interests: None declared DOI: 10.1136/annrheumdis-2019-eular.3938

\section{THU0637 ACADEMIC ACHIEVEMENT, EMPLOYMENT STATUS, WORK PRODUCTIVITY AND ACTIVITY IMPAIRMENT IN ADULTS WITH JUVENILE IDIOPATHIC ARTHRITIS (JIA): DETERMINANTS AND CONSEQUENCES}

Chengappa Kavadichanda, Karunya Ravi, Vir Negi. Jawaharlal Institute of Postgraduate Medical Education and Research, Clinical Immunology, Puducherry, India

Background: Changes occurring in childhood due to JIA leads to activity and work impairment during their transition to adulthood. The factors impairing work and overall activity among adults with JIA need to be explored to formulate policy decisions and rehabilitation measures.

Objectives: - To assess the level of academic achievement, employment, work productivity and activity impairment among adults suffering from JIA - To identify factors determining activity impairment among adults with JIA

Methods: Consecutive adults classified as JIA (1) were included. Consenting patients filled a questionnaire comprising of demographic details, occupational/educational status, Indian health associated questionnaire (iHAQ), Work Productivity and Activity Impairment score (WPAI) (2)in the language of their choice. Clinical evaluation for disease activity and damage was done and remission was assessed by Wallace criteria. Remission was defined as ever remission: $>3$ months and sustained remission: $\geq 6$ months of disease control. Appropriate statistical tests to assess association and correlation of various factors with WPAI were used.

Results: Demography $(n=51)$ is depicted in table 1 . Never attaining remission resulted in significantly higher college dropouts ( 8 vs $17, \mathrm{p}<0.05$ ), functional impairment (mean $\mathrm{HHAQ} 1.08$ vs $0.5, \mathrm{p}<0.05$ ) and articular damage (mean JADI A 3 vs $8, p<0.01$ ). Disease duration, JADI $A$ and iHAQ correlated well $\left(r^{2}>.400, p<0.05\right)$ with measures of WPAl (table 2$)$. Assessment of patient variables like gender, occupation, disease activity and remission status (figure 1) showed that women, especially the homemakers and individuals with moderate to high disease activity had significant activity impairment $(\mathrm{P}<0.05)$.

Conclusion: Early effective treatment directly impacts employment levels and activity in adults with JIA. Homemakers in middle- and low-income countries have the most impairment in activity as they cannot alter their work. Replacement costs for homemakers would be an added financial burden to the family and is seldom captured by studies. Our study highlights the need to look further into the indirect and intangible costs involving women that will help policy makers formulate effective economic policies for individuals with JIA.

\section{REFERENCES:}

[1] Petty RE, Southwood TR, Manners P, Baum J, Glass DN, Goldenberg J, et al. International League of Associations for Rheumatology classification of juvenile idiopathic arthritis: second revision, Edmonton, 2001. J Rheumatol. 2004 Feb;31(2):390-2.

[2] Reilly MC, Zbrozek AS, Dukes EM. The validity and reproducibility of a work productivity and activity impairment instrument. Pharmacoeconomics. 1993 Nov;4(5):353-65.

Table 1. Demographic, educational, occupational, health profile and WPAI measures of adults with JIA

\begin{tabular}{lccc}
\hline S.No & Parameter (N=51) & Median & IQR \\
\hline $\mathbf{1}$ & Age & 22 & 8 \\
$\mathbf{2}$ & Disease duration (years) & 9 & 10 \\
$\mathbf{3}$ & Duration of treatment (years) & 5 & 5 \\
$\mathbf{4}$ & WPAI Measures (in percentage) & 40 & 50 \\
& Overall Activity Impairment & 64.06 & 61.66 \\
& Overall Work Impairment (N=14) & 40 & 72.05 \\
& Presentism (N=12) & 33.03 & 51.14 \\
& Absenteeism (N=14) & Frequency (n) & Percentage (\%) \\
& Gender & $\mathbf{2 4 / 2 7}$ & $\mathbf{4 7 . 1 / 5 2 . 9}$ \\
$\mathbf{1}$ & Male/Female & $10 / 41$ & $19.6 / 80.4$ \\
$\mathbf{2}$ & Residential type & & \\
$\mathbf{3}$ & Urban/Rural & 1 & 2 \\
& Educational Status & 10 & 19.6 \\
& Illiterate & 14 & 27.5 \\
& Less than high school & 8 & 15.7 \\
& High School & 18 & 35.3
\end{tabular}

Graduate/Postgraduate or above Housewife
Unemployed/Quit job due to illness JIA Subtype

Systemic Arthritis Oligo Arthritis

Polyarthritis (RF-Negative)

Polyarthritis (RF-Positive)

Enthesitis-Related JIA

Undifferentiated Arthritis Deformity

Absent/Present

Remission

Never/Ever Remission

Sustained remission before/after $18 \mathrm{yrs}$

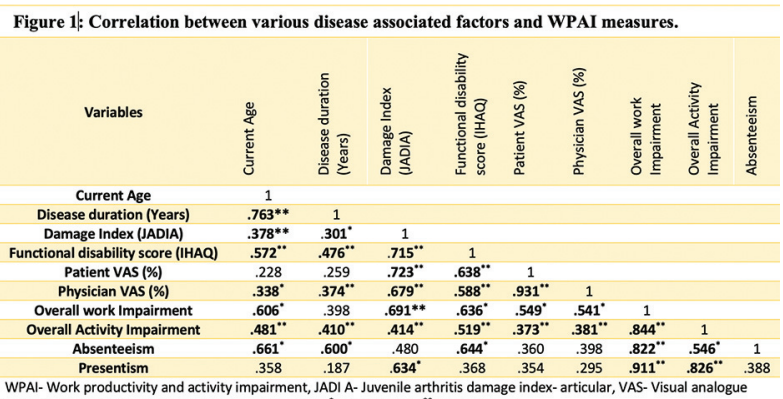

scale, IHAQ- Indian Health associated questionnaire. " P value $<0.05$, " P value $<0.00$
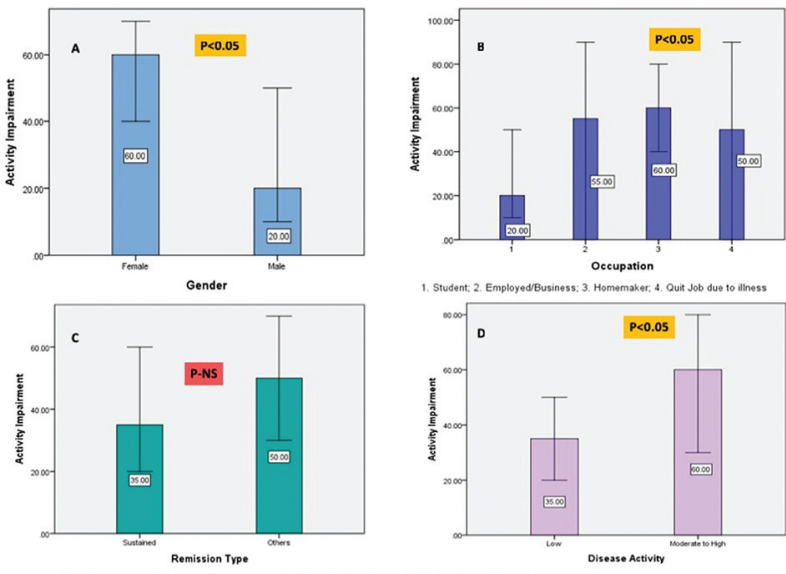

ocoupotion

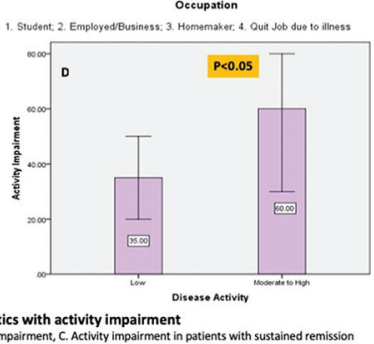

Figure 2: Association of patient and disease characteristics with activity
A. gender and activity impairment, B. Type of coccupation and activity imparirment, C. Activity impairment in patients with sustained remission

Disclosure of Interests: None declared

DOI: 10.1136/annrheumdis-2019-eular.5191

\section{THU0638 CONSIDERATIONS FOR IMPROVING QUALITY OF CARE IN RHEUMATOID ARTHRITIS AND ASSOCIATED COMORBIDITIES}

Tore K. Kvien ${ }^{1}$, Karel Pavelka ${ }^{2}$, Joaquim Polido-Pereira ${ }^{3}$, Anne Grete Semb ${ }^{1}$, Magnus Sköld ${ }^{4}$, Alejandro Balsa ${ }^{5}$, Neil Betteridge ${ }^{6}$, Maya Buch ${ }^{7}$, Patrick Durez ${ }^{8}$, Ennio Favalli ${ }^{9}$, Guillaume Favier ${ }^{10}$, Cem Gabay ${ }^{11}$, Rinie Geenen ${ }^{12}$, Ioanna GouniBerthold ${ }^{13}$, Frank van den Hoogen ${ }^{14}$, Alison Kent ${ }^{15}$, Lars Klareskog ${ }^{4}$,

Mikkel Ǿstergaard ${ }^{16}$, Maxime Dougados ${ }^{17}{ }^{1}{ }^{1}$ Diakonhjemmet Hosp, Oslo, Norway,

${ }^{2}$ Inst Rheumatology, Prague, Czech Republic; ${ }^{3}$ Hosp Santa Maria, Lisbon,

Portugal; ${ }^{4}$ Karolinska U Hosp, Stockholm, Sweden; ${ }^{5}$ Hosp U La Paz, Madrid,

Spain; ${ }^{6}$ Betteridge Assoc, London, United Kingdom; ${ }^{7}$ Chapel Allerton Hosp, Leeds, United Kingdom; ${ }^{8} \mathrm{Clin} \cup$ Saint-Luc, Brussels, Belgium; ${ }^{9}$ Gaetano Pini Inst, Milan,

Italy; ${ }^{10}$ KPMG, London, United Kingdom; ${ }^{11}$ Geneva U Hosp, Geneva, Switzerland;

${ }^{12}$ Utrecht U, Utrecht, Netherlands; ${ }^{13} \mathrm{U}$ Cologne, Cologne, Germany, ${ }^{14}$ Sint

Maartenskliniek, Nijmegen, Netherlands; ${ }^{15}$ Salisbury Hosp, Salisbury, United Kingdom; ${ }^{16}$ Rigshospitalet, Copenhagen, Denmark; ${ }^{17}$ Cochin Hosp, Paris, France

Background: The presence of comorbidities in patients with rheumatoid arthritis (RA) contributes to increased morbidity and mortality ${ }^{(1)}$. Patients 